\title{
Analysis of Stepped Basin V Type Solar Still with Different Water Depth and External Boosting Mirrors
}

\section{Sourabh Kumar Nougriaya ${ }^{\text {1* }}$ M. K. Chopra ${ }^{2}$, Bhupendra Gupta3}

\author{
'Sarvepalli Radhakrishnan University, Bhopal-462047, India \\ ${ }^{2}$ Department of Mechanical Engineering, Sarvepalli Radha- \\ krishnan University Bhopal- 462047, India \\ ${ }^{3}$ Jabalpur Engineering College, Jabalpur-482011, India \\ Study Area:Jabalpur, Madhya Pradesh, India \\ Coordinates: $23^{\circ} 14^{\prime} \mathrm{N}, 79^{\circ} 90^{\prime} \mathrm{E}$
}

Key words: Stepped solar still for different water depths ( $5 \mathrm{~mm}$, 10mm, and $15 \mathrm{~mm}$ )

\section{Introduction:}

Water is the blessings of God. It is really crucial for the life of individuals. Around 97 percent of water is saline and just 3 percent of the earth's water is safe for human consumption. For desalination, solar energy may use. worldwide solar stills are often used for desalination, but their productivity is limited. So it's a need to design improved techniques that should strengthen solar stills performance. Numerous researches have investigated strategies to increase efficiency (Gnanaraj etal., 2016).

Solar Distillation :Solar distillation is often a feasible choice to produce freshwater in arid areas where seawater is abundant. Solar is still used to generate freshwater for drinking, farming, and household use. Salt and certain other impurities like waterborne bacteria, microbiological and heavy metals are separated from the water during the distillation process. The outlet water becomes pure like rainwater (Yadav \& Kumar, 2016). The process acts like a greenhouse, where seawater evaporating and condensing on the cover's inner surface (Rubio et al., 2020). Solar distillation is a process of purifying water (saline \& brackish) through the use of solar energy. It is basically an analogy of the natural hydrological cycle adopted in solar distillation by man. It uses a device called 'Solar still'. This device consists of a glass cover, an insulated basin with brackish water, and a distillate collecting channel (Nougriaya et al., 2020).

\section{Abstract}

It's the right of all to get healthy and safe drinking water. Just o.5 percent of the earth has fresh water available. Solar desalination from solar still is the most desirable process for safe drinkable water at a very affordable cost. We work experimental and theoretical analysis on conventional and stepped basin $\mathrm{V}$ type solar still with different water depth and external boosting mirrors. This still is designed for experimental research in Jabalpur. This experimental work presents the result of four different setups of solar stills in January on the date of 21/01/2021 and 22/01/2021 with respect to time from 9:00 am to $4.00 \mathrm{pm}$. We have done three experiments. According to date 21/01/2021, we have conducted two experiments in equal Ambient Temperature $\left({ }^{\circ} \mathrm{C}\right)$ and Solar radiation $(\mathrm{w} / \mathrm{m} 2)$. In the same way on 22/01/2021 we have conducted one experiment.

\section{Experimental Protocol and Results:}

The experimentation has been performed at Jabalpur, India $\left(23^{\circ} 14^{\prime} \mathrm{N}, 79^{\circ} 90^{\prime} \mathrm{E}\right)$. The solar still used in this work is fabricated by $1 \mathrm{~mm}$ thick galvanized iron sheet. The still is further insulated with thermocol $10 \mathrm{~mm}$ thick in bottom and sides. It is further supported by a wooden frame from outside. The solar still is covered the top by transparent glass of thickness $4 \mathrm{~mm}$. The heights of high side and low side (middle) is $280 \mathrm{~mm}$ and $100 \mathrm{~mm}$. overall dimensions of the basin (outside) is $860 \mathrm{~mm} \times 500 \mathrm{~mm}$. Glass cover dimensions is $495 \mathrm{~mm} 460 \mathrm{~mm}$ ( 2 no.). The performance of the conventional basin $V$ type and proposed stepped basin $\mathrm{V}$ type solar still is verified under different parameters. These parameters are basin design, water depth, and boosting mirrors.

Experimental study: Experimental Overall thermal efficiency for conventional basin $\mathrm{V}$ type solar still can be calculated as (Gupta et al., 2016).

$$
E=\frac{(Q \times h)}{(A \times I)}
$$

Where,

$\mathrm{E}=$ Overall thermal efficiency

$\mathrm{Q}=$ Daily output (litre)

$\mathrm{h}=$ Latent heat of vaporization

$A=$ Area of the glass surface of the solar still $\left(\mathrm{m}^{2}\right)$

$\mathrm{I}=$ Average daily solar radiation $\left(\mathrm{MJ} / \mathrm{m}^{2}\right)$

*Corresponding Author: s.nougriaya@gmail.com 
Table-1: Experimental Overall thermal efficiency for conventional basin $\mathrm{V}$ type solar still

\begin{tabular}{|c|c|c|c|c|c|}
\hline $\begin{array}{l}\text { Time } \\
\text { (h) }\end{array}$ & $\begin{array}{l}\text { Ambient } \\
\text { Temp. }\left({ }^{\circ} \mathrm{C}\right)\end{array}$ & $\begin{array}{l}\text { Solar rad. } \\
\left(\mathrm{w} / \mathrm{m}^{2}\right)\end{array}$ & $\begin{array}{l}\text { Q Output } \\
\text { (litre) }\end{array}$ & $\mathrm{E}=\mathrm{Qh} / \mathrm{AI}$ & $\begin{array}{l}\text { Efficiency } \\
\%\end{array}$ \\
\hline 9 & 21 & 605 & $\mathrm{O}$ & $\mathrm{O}$ & $\mathrm{O}$ \\
\hline 10 & 25 & 688.6 & 0.06 & 0.118913822 & 11.89138 \\
\hline 11 & 26 & 744 & 0.095 & 0.174260428 & $17 \cdot 42604$ \\
\hline 12 & 30 & 840 & 0.12 & 0.194962043 & 19.4962 \\
\hline 13 & 29 & 1016 & 0.19 & $0.255^{21606}$ & $25 \cdot 52161$ \\
\hline 14 & 30 & 862 & 0.125 & 0.197902306 & 19.79023 \\
\hline 15 & 27 & 632 & 0.1 & 0.215938971 & 21.5939 \\
\hline \multirow[t]{2}{*}{16} & 25 & 563 & 0.06 & 0.145442377 & $14 \cdot 54424$ \\
\hline & & & Average & 0.172 & 17.2008 \\
\hline
\end{tabular}

Theoretical study: theoretical Overall thermal efficiency for conventional basin $\mathrm{V}$ type solar still can be calculated as (Gupta et al., 2017).

$$
\eta_{\text {still }}=\frac{\Sigma \mathrm{m}_{\mathrm{W}} \times \mathrm{L}}{\Sigma \mathrm{I} \times \mathrm{A} \times 3,600}
$$

$\mathrm{m}_{\mathrm{w}}=$ hourly distillate output $(\mathrm{kg})$

$\mathrm{L}=$ latent heat of vaporization $(\mathrm{Kj} / \mathrm{kg})$

$\mathrm{I}=$ daily average solar radiation $\left(\mathrm{W} / \mathrm{m}^{2}\right)$

$\mathrm{A}=$ Area of glass cover $\left(\mathrm{m}^{2}\right)$

Table 2 Theoretical distillate output and overall thermal efficiency for conventional basin $\mathrm{V}$ type solar still

\begin{tabular}{lllll}
\hline $\begin{array}{l}\text { Time } \\
(\mathrm{h})\end{array}$ & $\begin{array}{l}\text { Ambient } \\
\text { Temp }\left({ }^{\circ} \mathrm{C}\right)\end{array}$ & $\begin{array}{l}\text { Solar Radiation } \\
\left(\mathrm{w} / \mathrm{m}^{2}\right)\end{array}$ & $\begin{array}{l}\text { Mw Output } \\
(\mathrm{L})\end{array}$ & $\begin{array}{l}\text { Efficiency } \\
\%\end{array}$ \\
\hline 9 & 21 & 605 & 0.00 & 0.00 \\
10 & 25 & 688.6 & 0.0534 & 11.311 \\
11 & 26 & 744 & 0.1126 & 21.936 \\
12 & 30 & 840 & 0.1461 & 25.097 \\
13 & 29 & 1016 & 0.1905 & 26.782 \\
14 & 30 & 862 & 0.1672 & 27.975 \\
15 & 27 & 632 & 0.0924 & 21.233 \\
16 & 25 & 563 & 0.0601 & 15.542 \\
& & Average & & $18.73 \%$ \\
\hline
\end{tabular}

In the same way as shown in table 1 and 2 we have done Experimental and Theoretical analysis on $\mathrm{V}$ type conventional basin solar still, V type stepped basin solar still, V type stepped solar still with different water depths $(5 \mathrm{~mm}, 10 \mathrm{~mm}$, and $15 \mathrm{~mm})$ and $\mathrm{V}$ type stepped basin solar still with External boosting mirrors (singleand double).

\section{Discussion:}

This experimental work presents the result of four different setups of solar stills in January on the date of 21/01/2021 and 22/o1/2021 with respect to time from 9:00 am to $4.00 \mathrm{pm}$. We have done three experiments. According to date 21/o1/2021, we have conducted two experiments in equal Ambient Temperature $\left({ }^{\circ} \mathrm{C}\right)$ and Solar radiation $(\mathrm{w} / \mathrm{m} 2)$. In the same way on 22/01/2021 we have conducted one experiment. The result of the efficiency and output of water forall three experiments aregiven below. a) For Conventional Basin V Type Solar Still Experimental and Theoretical output of water is $0.750 \mathrm{l}$ /day and $0.8224 \mathrm{l}$ /day, as well as Experimental and theoretical results of efficiencies, are $17.201 \%$ and $18.73 \%$.

b) For Stepped Basin VType Solar Still With $5 \mathrm{~mm}$ Water Depth Experimental and Theoretical output of water is 1.040 1/day and 1.0662 1/day, as well as Experimental and theoretical results of efficiencies, are $23.852 \%$ and 24.473 .

c) For Stepped Basin VType Solar Still With $10 \mathrm{~mm}$ Water Depth Experimental and Theoretical output of water is 0.930 l/day and 0.9799 1/day, as well as Experimental and theoretical results of efficiencies, are $21.329 \%$ and $22.718 \%$.

d) For Stepped Basin VType Solar Still With $15 \mathrm{~mm}$ Water Depth Experimental and Theoretical output of water is $0.830 \mathrm{l} /$ day and $0.8745 \mathrm{l}$ / day, as well as Experimental and theoretical results of efficiencies, are $19.036 \%$ and $20.02 \%$.

e) For Stepped Basin V Type Solar Still Without External Boosting Mirrors Experimental and Theoretical output of water is $1.235 \mathrm{l} /$ day and $1.234 \mathrm{l} /$ day, as well as Experimental and theoretical results of efficiencies, are $25.100 \%$ and $25.459 \%$.

f) For Stepped Basin V Type Solar Still With Single External Boosting Mirrors Experimental and Theoretical output of water is $1.405 \mathrm{l}$ / day and $1.433 \mathrm{l}$ / day, as well as Experimental and theoretical results of efficiencies, are $28.555 \%$ and $29.45 \%$.

g) For Stepped Basin V Type Solar Still With Double External Boosting Mirrors Experimental and Theoretical output of water is $0.745 \mathrm{l}$ / day and $0.789 \mathrm{l}$ / day, as well as Experimental and theoretical results of efficiencies, are $15.141 \%$ and $15.995 \%$.

\section{References:}

Gupta, B., Shankar, P., Sharma, R. \& Baredar, P. (2016): Performance enhancement using nano particles in modified passive solar still. Proc. Technol., 25:1209-1216.

Gupta, B., Kumar, A. \& Baredar, P. V. (2017): Experimental investigation on modified solar still using nanoparticles and water sprinkler attachment. Front. Mater., 4:1-7.

Gnanaraj, S. J. P., Ramachandran, S. \& Mageshwaran, G. (2016): Experimental analysis of single basin solar still with internal reflector and sensible heat storage medium. Int. J. Chemtech Res., 9(8):328-337.

Nougriaya, S.K., Chopra, M. K. \& Gupta, B. (2020): Solar still design classification: a simple desalination technology to achieve treated water. $A m b . S c i ., 07(2): 01-05$.

Rubio, E., Zayas, J.L.F. \& Gandara, M.A.P. (2020): Current status of theoretical and practical research of seawater single-effect passive solar distillation in mexico. L.Mar. Sci. Eng., 8(2): 1-17.

Yadav, C. \& Kumar, M. (2016): Recent advances in stepped and weir type solar still. Int.J. Rec. adv. Eng. Technol., 4(1):83-90. 